\title{
Professional Teacher Competences at Elementary Education in Digital Era
}

\author{
Bundu' ${ }^{1}$ Patta ${ }^{2 *}$ \\ \{patta_unm@yahoo.co.id*,patta.bundu@unm.ac.id*\} \\ ${ }^{1,2}$ State University of Makassar, Indonesia
}

\begin{abstract}
Basic education changes rapidly espesially at digital era both at 4.0 era and society 5.0. To change the condition from traditional learning to new learning is still need to improved especilly at the implementation level. There are three main points should be faced: time, change, and education; creativity and classroom interaction; and teacher's competences. In $21^{\text {st }}$ century learning involves five types of interactions: (a) learnercontent, (b) learner-teacher, (c) learner-learner, (d) learner-interface and (e) learnercommunity. To overcome these fenomena, teachers should master the four competences of the teacher that conneted firmly one each other, pedagogical, professional, personality, and social competency. These competences should based on ${ }^{21 s t}$ century learnig, learning to know, learning to do, learning to be, and learning to libe together. Finally, creativity should be develop in order to adapt every change in educational program.
\end{abstract}

Keywords: competency, change, interaction, creativity

\section{Introduction}

Teaching and learning at 21st century was influenced by technology. Technology and communication device have changed the interaction model in the society. Learning had gone beyond the school wall boundary. Technology does not recognize the distance, and predict future learning. Knowledge can change to anyone and community at any time. A country that can adapt and interact with the change will be developed fast. Unfortunately, we only arrive at "know" level, but is still lack of "implementation". Thus, the word "quality assurance" must be changed to "quality improvement". "Quality" moves so fast; something is valuable now will be substituted by a new one with higher quality only in a few weeks. In early 2000, many scientist said that a hand-held device is the 'true' personal computer (Soloway, 2001), its small size makes it highly portable and adaptable and students may use it at anytime and anywhere (Powel \& Badlry, 2001); (Sheild \& Poftak, 2002). The benefit students gain easy access to their personal computers.

During the last 10 years there was a huge change in education, espesially at elementary school level. The changes happen very fast and become the main topic at every seminar and conference as quoted in the Sydney Morning Herald - April 16th 2004 (Suyanto \& Asep, 2012). The educational change moves from traditional learning to new one as in diagram 1. 


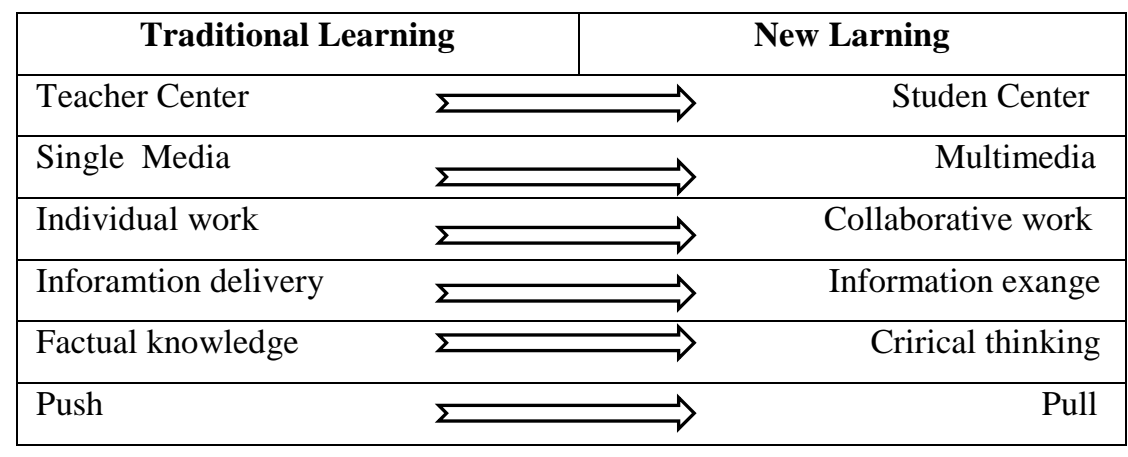

Diagram 1. Change in Education (Suyanto \& Asep, 2012)

Based on the diagram above, it is clear that the process of learning should be moved from teacher centered to students centerd, multimedia is used to replace single one, students' individual work should be changed to become collaborative work, information communication is multi dimension that its function is as exchanged information, and factual leaning changes to be critical thinking based learning. More specific, the change is dealing with from traditional learning model that is from integration to transformation .learning, schooling system to be life long learning, knowing to understanding, broadcast/transmission learning to constructivistic learning, and learning technology skills to developing 21 st century skills.

Nowadays, it is viral and is almost talked about in many seminars are learning in digital era 4.0 that focuses on 4 learning characteristics. Those are creativity, critical thinking, collaborative, and communication with supporting elements; standard and assessment, curriculum and instruction, professional development, and learning environment. The way of cummunity's life changes rapidly in many aspects. Some of them are: 1) transportation system; online based vehicles change taxi known as luxurious cars before, 2) publlic service and infrastructure becomes simple by the presence of smartphone, 3 ) financial system; where people don't have to go to the bank but it can be served at home by clicking numbers through their smart phone, 4) health service system; patients don't have to go to the hospital, but the doctor will come and visit them, and 5) ATM will be disappeared not any longer as well.

Those conditions declared in Japan with its hastag "Society 5.0". Japan as the founder of Society 5.0 realizes that many challenges need to be overcome from now on. Fukuyama (2018) said that Japan is promoting Society 5.0 by introducing digital technologies in a variety of systems, as well as accelerating its implementation to achieve a society in which all citizens are dynamically engaged. Moreover, Fukuyama (2018) pointed out that:

" ... at the same time, the trend toward creating new value through digital technologies and conributing to future society can now be seen throughout the world. The evolution of digital transformation is not a path that can be avoided. Therefore, these negative aspects should be shared and recognize, and try to accelerate the participation of multi-stakeholders and share best practices". 
Several phenomena may happens in the era of society 5.0 as illustrated below:

Society 5.0 will change the world

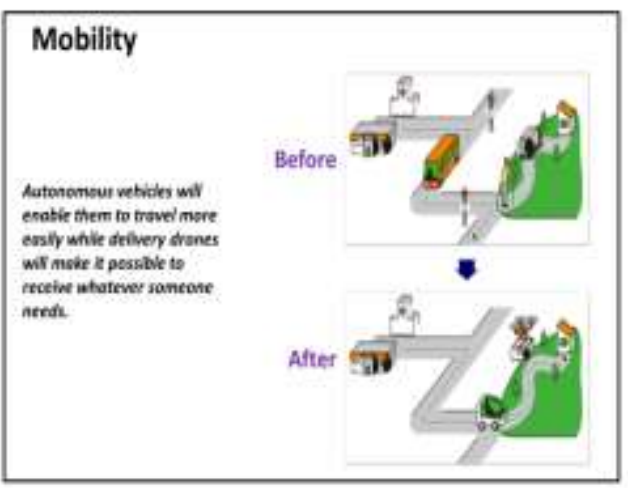

\section{Society 5.0 will change the world}

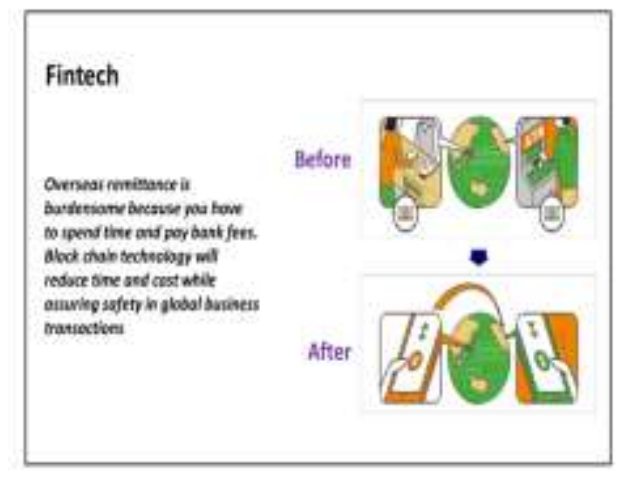

Those phenomena will influence on school system especially at elementary school. All systems will be dominated by digital information technology. Should it be fight against it? Or just follow it? Many predictions that school will become on line based learning/web learning and communication technology. Net working, dialogue, and inter change information will facilitate the collaborative learning. Education in 2030 will focus on the use ICT on teaching learning activities, so where is the teachers? Human interaction physically is still needed for education in the future.

\section{Elementary Education at Digital Era}

As science and technology develops rapidly, elementary education system should change although it is not balanced with the implementation in the field. There are three important competences to maintain teachers' existence in the digital era 4.0. They are teachers' competence actualization especially personality and professional competence, adoption and adaptation toward education change, and creativity and interaction pattern in learning.

\section{Professional Teacher Comptency}

There are four main teacher competences that teacher should master; pedagogy, professional, personality, and social competency. The diagram is made to compare with the Education for All from UNESCO as the charateristics of 21st century learning; learning to know, learning to do, learning to be, and learning to live together. A teacher should know the pedagogical concept in teaching and learning. To be professional the teacher should be able to implement the concepts properly in the classroom. Moreover, a teacher should have a good personality, and live together in the dynamic society.

In short, we can see on the following diagram (diagram 2). 


\begin{tabular}{|l|l|}
\hline Teachers' Comptences & Educational for All (UNESC)) \\
\hline Pedagogy & Learning to know \\
\hline Professional & Learning to do \\
\hline Personality & Learning to be \\
\hline Social & Learning to live together \\
\hline
\end{tabular}

Diagram 2. Teachers' Competences \& Educational for All

The first competency is pedagogy and the first step in Educational fo All (EfA) is learning to know. It means that a teacher should know a lot of of pedagogical content or concept. This is the first argument why a teacher should graduate from teacher program institute. It is also a basic argument why the teacher should attend teacher professional education. The teachers should master pedagogical competency based on Permendikbud No.16 Tahun 2007, as follows:

a. Master students' characteristic physically, moral, spritual, social, cultural, emotional, and intellectual.

b. Master learning theory and principles of educative learning.

c. Develop curriculum related to subject matter.

d. Provide educative learning.

e. Use information technology and communication for teaching.

f. Facilitate students' potential development in order to actualize students' potency.

g. Communicate effectively, empathy and polite with students.

h. Provide assessment and evaluation of students' achievement.

i. Use the result of the assessment and evaluation for learning.

j. Do reflective action to improve learning quality.

Conceptually, teachers' mastery on pedagogy is good. They know exactly appropriate criteria needed in teaching. They do understand that in teaching they have to recognize students' character, master learning theory, communicate effectively, do well assessment, etc. Among those competencies, however, learning concept is still questionable. It can be seen from the result of knowledge testing in teacher profession education that still high percentage not pass the test.

The second conpetency is professional competence that is a set of competence and skill in order to master subject matter comprehensively. A professional teacher should master 1) subject matter, 2) manage teaching-learning program, 3) manage the classroom, 4) use media and learning source. Or a) develop standard competence and basic competence suitable to subject matter, b) master subject matter, concept, pattern, and science structure widely and deeply suitable to the subject matter, c) develop subject matter to the learning creatively, d) develop sustainable professionalism by carrying out reflective action (classroom action research) (http://:www.dasarguru.com/kompetensi-profesional).

There many studies about concept and definition of professional competence. One of them is individual's competence to do what he/she understands well. A teacher said competence when he/she can do pedagogy well. When a teacher understands the use of learning model and can do it well, means he/she has teacher professional characteristic. However, many teachers understand pedagogy concept but can't apply it in learning process. 
Moreover, personality competence as stated in Undang-Undang Republik Indonesia Nomor 14 Tahun 2005 and government regulation Number 19 Tahun 2005 about Standard of National Educations is individual's competence like good character, authoritative, wise, and example for the students. And, there are 5 social competence a teacher should have as it in Permendiknas No. 16 tahun 2007; 1) communicate with students and their parents well, 2) sympathetic, 3) join school committee well, 4) have a good friendship with colleagues, and 5) understand the environment.

Related to education for all (EFA) from UNESCO those three teachers' competences will form stronger personality and can adapt to education in 21 st century. When a teacher understands and learns to know deeply about pedagogy, and do what he/she knows in the classroom (learning to do), he/she is a professional teacher. But, it's not enough. A teacher should have the personality of the teacher, and live in the community - that is social competency (learning to live together).

\section{Time, Change, and Education}

More than 25 years ago, Singh (1991) points out the perception of a difference between "before" and "after". There is also a sense that "before" is irreversible, while "after" except that sliver of time that is bounded to the immediate present is unknowable, unpredictable, unforeseenable. However, the human quest $\mathrm{t}$ know, to predict, to anticipate has continued unflagging. Its nature however, over time has changed in the consciousness that possibly the future time is not after all unindirectional in the image of "time's arrow", but has multiple possibilities.

The future is not a single future but a number of possible future. Last experience and today's condition will give prediction in the future that can be complicated. Clearly, the future is neither formed by previous and present condition and nor the consequency of activity carried out now. As Singh (1991) states "what gives the past and the present their influence in the shaping of the futures is the collective, societal awareness of possibilities and of choice".

The development of education is more focused on conciously future-oriented. The aim of education aims is important, because the students at present will work for the next 2 decades. By accelerating, the next generation is not only transition generation but new generation in that era. In a very real sense, the future is now - in our hand. Whatever we prepare, plan, and do at present, the impact will come up next time. Thus, planning must be supported by clear vision and mission with deeply reviewed. "Without vision the future may be only an illusion" (Sin gh, 1991). Bertrand de Jouvenel in Singh (1991) states:

"if society tends on the whole to conserve the present state of affairs, our present

knowledge has a high chance of being valid in the future. On the other hand, the future validity of our knowledge becomes increasingly doubtful as the mood of society inclines towards change, and the changes promise to be more rapid".

A reactive educational policy and its practice places a high position in relation to "behavioural objectives" focused on individual. Otherwise, future oriented education actively promotes innovations and motivate the community to get involved. "The future is not some 
place we are going to, it is one we are creating' that reaction implies a vision and choice" (Bertrand van Jouvenel, in Singh, 1991).

\section{Teacher Creativity and Classroom Interaction}

According to Riche (2014) the teacher should create classroom to be full of energy with smiling students. This condition will happen when the teacher is creative. Creativity makes classroom success. Riche (2014) points out some definition of creativity. They are; creativity is innovation; creativity is thinking outside the box; creativity is improvisation; craetivity is professional growth; creativity is being a risk taker; and creativity is passion. In this case, doing the same thing over and over expecting different results is really not creativity, but come up with something else that will work for the students, is creativity. Also, everything does not always have to be black and white, one problem might be have more than one solution. Sometimes it is also happened learning activities do not turn out the way we planned. In this condition, the teacher can choose another way from different angle. If we can not figure out what to do, we can use co workers as resources, look at, search and see what has worked for other teachers around the world. Is it the new planning alwas running well? Perhaps some have worked and some have not, but it is better than being stuck in the same pattern that is not working. Finally, be passionate about what you are doing. You are there to inspire students to become life long learners. If you want them to love learning, you have to love what you are teaching" (p....).

There are many suggested activities to promote creativity in the classroom. Riche (2014) suggested 22 simple ideas for harnessing creativity in the elementary classroom. Raudis (2018) proposed 7 experiential learning activities to enggage students in creative activities. Knapen (2018) suggested 20 interactive teaching activities for the interactive classroom. Read (2018) try to build creativity through classroom games, and many other things. It is very important to note, according to Riche (2014):

For those of you who are trying to figure out how you'll find the time to integrate all this into an already busy teaching day. It will take longer to teach a lesson three times than it will to teach it once using a little creativity. Make time for creativity. Most of the above creative activities take only a few minutes to do. They also require very little prep time and cost very little money, if any. So go ahead -- be a risk taker and try at least one of these ideas.

Riche (2014) stated firther that the teacher should create classroom might see a room full of energy and smiling students. This condition will happen when the teachers using creativity in the classroom. Creativity is vital for a classroom to be successful. Furthermore, she suggests that for professional teaher should understand clearly that creativity has not to do mostly with the arts. Classroom environment would benefit from a teacher blessed with the gift of artistic talent, creativity is many other things.

The following was showed 22 learning form that might be increasing students creativity (Riche, 2014). 


\begin{tabular}{|c|c|c|c|}
\hline $\begin{array}{c}\text { The Game of } \\
\text { Learning }\end{array}$ & $\begin{array}{c}\text { The Artsy Side of } \\
\text { Creative }\end{array}$ & $\begin{array}{l}\text { Creative } \\
\text { Science }\end{array}$ & $\begin{array}{c}\text { Creative Time } \\
\text { Saver }\end{array}$ \\
\hline $\begin{array}{l}\text { 1.I know a word } \\
\text { 2.Ryme time } \\
\text { 3.Parctice counting } \\
\text { 4.Spelling review } \\
\text { 5.I need synonym } \\
\text { 6. Reinforce other skils } \\
\text { 7.Rolls dice } \\
\text { 8.Sight word slap games }\end{array}$ & $\begin{array}{l}\text { 9. Use different voices } \\
\text { 10. Dress in costumes } \\
\text { 11. Turn your class into } \\
\text { learning environment } \\
\text { 12. Create class song }\end{array}$ & $\begin{array}{l}\text { 13. Smart bound - } \\
\text { journal different } \\
\text { of friction } \\
\text { 14. Coloring into } \\
\text { beakers of cold } \\
\text { and warm water } \\
\text { 15. Use ice and talk } \\
\text { about gravity }\end{array}$ & $\begin{array}{l}\text { 16. Use classmate } \\
\text { question } \\
\text { 17.Pair higher - lower } \\
\text { 18.Put them into } \\
\text { literature cycle } \\
\text { 19. Read another } \\
\text { writing } \\
\text { 20.Data collection } \\
\text { 21. Math problem for } \\
\text { the day jurnal }\end{array}$ \\
\hline
\end{tabular}

Diagram 1. 22 learning form that might increasing students creativity

The results of research suggest technology based learning will impact many things as follows:

- improve quality of instructional activities, especially in science;

- enhance student communication and collaboration;

- improve student organizational skills;

- enhance student motivation;

- promote of student autonomous learning. (Crawford \& Vahey: 2002).

A better interaction will be easier creativity formed. Leh, Kouba, and Davis (2005) had reviewed literature on learning community, community learning, interaction, 21st century learning and ubiquitous computing and presented work conducted by a teacher who used handheld device, one of the 21 st century tools, in a sixth grade classroom in the USA. They suggest that 21 st century learning involves five types of interactions: (a) learner-content, (b) learnerteacher, (c) learner-learner, (d) learner-interface and (e) learner-community. They also recommend that professionals explore the potential of hand-held devices in education and conduct research on its effectiveness in learning.

\section{Conclusion}

1. Elementary education change so fast especially in digital era 4.0 and society 5.0

2. Teacher should adapt and adopt the change by strengthening their competences, especially personality and professional competence. Those can be done by mixing them with $21 \mathrm{st}$ century learning; learning to know, learning to do, learning to be, and learning to live together.

3. Teacher should build creativity in the classroom. Changing is a must and future is unpredictable. But, teacher's creativity in the classroom will be able adjust the change. 


\section{References}

Crawford, V. \& Vahey, P. (2002) Palm education pioneers program. Available online at: http://www.palmgrants.sri.com/PEP_Final_Report.pdf (accessed August 20, 2019).

Fukuyama, Mayumi (2018).Society 5.0. Aiming for a New Human Centered Society. Japan SPOTLIGHT July/August us 2018. https.: www.jef.or.jp/journal.

Leh, Amy S. C., Barbara Kouba, and Dirk Davis. (2005). Twenty-first century learning: communities, interaction and ubiquitous computing. Educational Media International, Vol. 42, No. 3, September, pp. 237-250.

Pownell, D. \& Bailey, J. (2001). Getting a handle on handhelds.http://electronicschool .com./ 2001/06/0601handhelds.html. (accessed Agustus 20, 2019).

Raudis, Justin (2018). 7 Experiential Learning Activities to Engage Students. http://www. prodigygame.com/blog/teaching-strategies.

Read, Mins. (2018). Top 10 Classroom Games. https:www.quizalize.com/2018/03/02/ classroom-games.

Riche, Trisha (2014). 22 Simple Ideas for Harnessing Creativity in the Elementary Classroom. https://www.edutopia.org/profile/trisha-riche.

Ruben, Knapen (2018). 20 interactive teaching activities for in the interactive classroom. https://www.bookwidgets.com/blog/2016/10.

Shields, J. \& Poftak, A. (2002). A report card on handheld computing, Technology and Learning, 22 (7).

Singh, Raja Roy. (1991). Education for Twenty - Fist Century: Asia Pasifik Perspectives. Bangkok: APEID - UNESCO.

Soloway, E. (2001). Supporting science inquiry in K-12 using palm computers: a palm manifesto. http://www.pdaed.com/features/palmminifesto.xml. (accessed Agust 20, 2019).

Suyanto \& Asep. ISTE. (2012). National Education Technology Standards for Teachers (USA). Weiser, M. (1991) The computer for the twenty-first century, Scientific American, 265(3), 94-104. 